\title{
Товарная интервенция - механизм защиты сельскохозяйственных товаропроизводителей и обеспечение продовольственной безопасности региона ${ }^{1}$
}

\author{
Александр Пахомов, Василий Дарбасов, Михаил Охлопков, \\ Екатерина Федорова, Михаил Соломонов
}

Якутский научный центр Сибирского отделения Российской академии наук, г. Якутск, Россия

\author{
Информация о статье \\ Поступила в редакиию: \\ 16.11 .2018 \\ Принята \\ к опубликованию: \\ 27.05.2019 \\ УдК 346.543: 338.43 \\ JEL Q13, Q18
}

\section{Ключевые слова:}

регулирование рынка, сельскохозяйственная продукция, закупочная, товарная интервенции

\begin{abstract}
Аннотация
Статья написана в связи с выходом в 2018 г. последней редакции постановления Правительства Российской Федерации «O государственных закупочных интервенциях сельскохозяйственной продукции». Целью исследования является обоснование продвижения государственного регулирования рынка местной сельскохозяйственной продукиии в виде закупочных интервенций в регионах. Проведен анализ существуюших зарубежных и отечественных государственных закупочных интервениий, дано обоснование закупочных интервенций в регионе, а также выработаны предложения по продвижению закупочных интервенций с федерального центра в регионы.
\end{abstract}

Commodity Intervention is Mechanism of Protection of Agricultural Commodity Producers and Food Security of Region

Alexander Pakhomov, Vasily Darbasov, Mikhail Okhlopkov, Ekaterina Fedorova, Mikhail Solomonov

\section{Abstract}

This article was written in connection with a September 2018 release of the latest edition of a Regulation of the Russian Federation Government on government purchasing interventions of agricultural products. An aim of the authors of the article is substantiation of promotion of the state regulation of a market of the local agricultural products in the form of the purchasing interventions in regions. The authors analyzed the existing foreign and domestic government purchasing interventions,

\section{Keywords:}

market regulation, agricultural products, purchasing, commodity interventions

1 Исследование выполнено в рамках государственного задания в части проведения НИР по теме «Социально-экономическая безопасность регионов Восточной Арктики: проблемы взаимообусловленности и трансформации в современных условиях, мониторинг, оценка, разработка комплекса государственных мер по ее повышению (на примере Республики Саха (Якутия)), № АAАА-А17-117031410034-1 DOI: https://dx.doi.org/10.24866/2311-2271/2019-3/55-66 
comments on the latest version of the Regulation of the Russian Federation Government on the government purchasing interventions, the substantiation of the purchasing interventions in the region and development of proposals to promote the purchasing interventions from the federal center to the regions. Relevance of the promotion of the purchasing interventions from the federal center to the regions follows from Russian particularity: remoteness of the regions from the center, weak regional transport infrastructure, necessity to replicate a federal technology of the state regulation of the agricultural product market in the regions of the Russian Federation. In the Republic of Sakha (Yakutia), repeated attempts were made to create compensation funds of the regulation of agricultural product prices. However, in the region there is no full-fledged intervention fund effectively influencing sales of the agricultural products. Consequently, in conditions of the Republic, where a shortage of the agricultural products, raw materials and food is acute, implementation of the commodity intervention is the necessary condition for the regulation of the agricultural market. For the Republic of Sakha (Yakutia), in our opinion, it is advisable to carry out the commodity interventions concerning beef, meat of young horses, venison, fish, dairy products, game, fruits of wild plants and even for rough and succulent fodder for livestock. The latter are relevant due to droughts and floods that regularly occur in a area of the region. Manufacturing costs of the local products will always be higher than the ones of imported food, given the harsh natural and climatic conditions, the remoteness of agricultural commodity producers from the sale markets in the conditions of absence of the transport infrastructure. In this regard, the prices of the local products should be regulated by the state in order to support the local producers. Obviously, the government regulation should not replace market functions or impede operation of its laws. Its main task is to mitigate undesirable consequences of manifestations of market power. One of the main regulatory methods is the commodity intervention.

\section{Понятийный аппарат и механизм зерновых интервенций}

Закупочная интервенция осуществляется в форме организации закупок и проведения залоговых операций с сельскохозяйственной продукцией, сырьем и продовольствием.

Товарная интервенция - это мероприятия по организации продажи сельскохозяйственной продукции из федерального и региональных продовольственных фондов, которые проводятся в целях стабилизации цен на рынке сельскохозяйственной продукции, сырья и продовольствия, и поддержания уровня доходов сельскохозяйственных товаропроизводителей [8].

Закупочные интервенции осуществляются в случаях, когда рыночные цены на сельскохозяйственные продукцию, сырье и продовольствие опускаются ниже минимального уровня или в случае, когда товаропроизводители в сфере производства не в состоянии реализовать сельскохозяйственные продукцию, сырье и продовольствие из-за сокращения спроса на них.

Государственные закупочные и товарные интервенции осуществляются в отношении зерна, семян масличных культур, шерсти, мяса крупного рогатого скота, свиней, птиц, масел растительных, сахара, масла животного происхождения и для сухого молока.

С официального сайта агента Министерства сельского хозяйства Российской Федерации (далее - Минсельхоз РФ) по зерновым интервенциям $\mathrm{AO}$ «Объединенная зерновая компания» [2] излагается механизм закупочных и торговых интервенций для регулирования рынка зерновых в стране. Перед началом летнего сезона Минсельхоз РФ устанавливает на предстоящий посевной период цены для проведения закупочных интервенций, а также определяет на конкурсной основе организацию-агента министерства для их технического осуществления. Агент заключает договоры хранения с элеваторами в регионах страны и кредитное соглашение с банком на 
приобретение зерна, подготавливает электронные площадки для осуществления торгов.

В случае возникновения ситуации значительного снижения стоимости зерна на внутреннем рынке - обычно это происходит во время уборочной кампании - объявляется дата начала закупок. С этого времени в зернопроизводящих регионах, в которых было зафиксировано резкое снижение цен (эта ситуация может касаться и всей страны), на электронных площадках начинается приобретение зерна. То есть появляется крупный покупатель с гарантированной оплатой поставленного товара, что стабилизирует стоимостные показатели внутреннего рынка.

Механизм покупки зерна на торгах следующий. Объявляются дневные сессии с определенным количеством лотов на том или ином базисе (элеваторе). Участвующие в торгах сельхозпроизводители формируют свои предложения от верхней планки цены, утвержденной Минсельхозом РФ. Выигрывает тот, кто предлагает более низкую цену. Приобретенное агентом зерно формирует государственный интервенционный фонд.

С 2014 г. при проведении закупочных интервенций стал применяться механизм обратного выкупа зерна. Это очень полезная опция для зерновиков. Так, осенью при условии избыточного предложения на рынке выращенную продукцию, стоимость которой невысока, можно реализовать по умеренным ценам интервенции в Государственный Интервенционный Фонд. В дальнейшем при установлении более благоприятной ценовой конъюнктуры сельхозпроизводителю предоставляется возможность выкупить проданную ранее партию зерна из фонда по стоимости продажи, возместив при этом расходы агента по хранению и страхованию. Это позволяет аграриям, с одной стороны, в осенний период получить оборотные средства на проведение сезонных работ, а с другой, после обратного выкупа реализовать зерно с максимальной маржой по выгодным рыночным ценам.

Наряду с закупочными интервенциями на зерновом рынке применяются товарные интервенции, которые выполняют обратную задачу — сглаживают ценовые пики при резком увеличении стоимости зерна. После объявления о начале действия товарных интервенций на электронных торгах для мукомольных предприятий из госфонда предлагается продовольственное зерно, а для животноводов - фуражное. Предприятие, дающее за конкретную зерновую агрокультуру более высокую цену, объявляется победителем. Таким образом, осуществлялся процесс накопления и расходования интервенционного зерна, и эта мера гармонично работала и обеспечивала регулирование внутрироссийского рынка зерна.

\section{История вопроса}

Попытки активного регулирования продовольственного рынка, в том числе за счет товарных интервенций, предпринимались с 30-х гг. ХХ в. в развитых странах. «Новый курс» в США во время Великой депрессии принял федеральные программы поддержки цен на сельскохозяйственную продукцию и множество других программ, направленных на достижение ряда социальных и экономических целей [15]. В США огромный рост производительности сельского хозяйства наблюдается со времени введения законодательства о поддержании цен на сельскохозяйственные продукты в 1933 г. [16]. 
Неолиберальное направление экономической мысли под интервенцией на рынке признают форму вмешательства государства в функционирование рыночных механизмов с целью его совершенствования, особенно в тех областях, где он (рынок) не в состоянии работать с общественной эффективностью $[5-7,10]$. Капитализм давно пришел к пониманию «Логического обоснования субсидий» сельскому хозяйству, изложенных в «Экономикс» К.Р. Макконнелл и С.Л. Брю [14].

Постановлением Правительства РФ при Минсельхозпроде в 1994 г. была создана Федеральная продовольственная корпорация для регулирования продовольственного рынка, в том числе с помощью закупочных интервенций. Развитие закупочных и торговых интервенций в Российской Федерации перетерпела значительные колебания падения и взлетов и осуществляется в настоящее время в отношении только зерна, что связано со значительными колебаниями в его производстве и ценовой конъектуры. Но еще в ноябре 2017 г. министр сельского хозяйства Российской Федерации А. Ткачев заявил о необходимости закрыть зерновые интервенции в связи с рядом обстоятельств [3]:

- нехваткой финансирования со стороны федерального бюджета;

- необходимостью рыночной переориентации зерновых хозяйств на твердые сорта пшеницы на экспорт и на фураж - бобовые культуры;

- необходимостью перехода на другой способ регулирования государственной поддержки зерновых хозяйств - субсидирования железнодорожных перевозок зерна на экспорт;

- загруженностью элеваторов федерального интервенционного фонда мягкими сортами пшеницы 3-5 классов 3-го и 4-го года хранения.

Выход в свет последней редакции вышеуказанного постановления, видимо, был вызван этими обстоятельствами. В отношении других видов сельскохозяйственной продукции, сырья и продовольствия закупочные интервенции не осуществлялись.

В Министерстве сельского хозяйства Республики Саха (Якутия) предпринимались неоднократные попытки создания компенсационных фондов регулирования цен сельскохозяйственной продукции при агентах министерства: ФАПК «Туймаада», «Якутия», «Сахабулт», АО «ТуймаадаАгроснаб» и т.д. Однако в регионе отсутствует полноценный интервенционный фонд, эффективно влияющий на сбыт сельскохозяйственной продукции.

Следовательно, в условиях Республики Саха (Якутия), где остро ощущается дефицит сельскохозяйственной продукции, сырья и продовольствия осуществление товарной интервенции является необходимым условием регулирования сельскохозяйственного рынка, обоснование которого изложено в следующем разделе.

\section{Востребованность региональной торгово-закупочной интервенции}

Продовольственный рынок республики имеет свои характерные особенности.

1. Это прежде всего территория Якутии в 3 млн км², более половины которой является труднодоступной [11], где критериями труднодоступных и отдаленных местностей признаются отсутствие круглогодичного автотранспортного сообщения, водного сообщения, наличие естественных 
преград для передвижения любого вида наземного транспорта и отсутствие оборудованных посадочных площадок для авиационного транспорта, а также значительная отдаленность местности от улусного (районного) центра.

2. В регионе сохранены все виды традиционного природопользования. Это достигнуто на основе общественного согласия о том, что серьезность кризисных условий, с которыми сталкивается сельская местность, угрожает сельским районам до такой степени, что контрмеры для сохранения сельскохозяйственного производственного потенциала, независимо от формы или потенциальных политических экономических последствий, крайне необходимы [6]. Из 48 городских и 361 сельских поселений [12] согласно вышеуказанному Закону 185 населенных пунктов и 163 производственных участка [11] отнесены труднодоступным.

3. Труднодоступность и крайняя разбросанность являются критическими условиями товарности сельскохозяйственного производства. В то же время, эти условия и в дополнение к ним устойчивые холода в течение 7-9 месяцев в году являются и «сравнительными преимуществами» [13] сельскохозяйственной продукции региона. Ими являются относительная экологическая чистота Крайнего Севера, являющаяся «стерильным родильным домом» для перелетных птиц Южной Азии, Австралии, Океании и других представителей флоры и фауны, а также домашних животных. Соответственно практически вся местная продукция предпочтительна для покупателей.

Для Республики Саха (Якутия) товарные интервенции, на наш взгляд, целесообразно проводить в отношении говядины, жеребятины, оленины, рыбы, молочных продуктов, дичи, плодов дикоросов и даже для грубых и сочных кормов для скота. Последние актуальны из-за засух и наводнений, регулярно происходящих в том или ином районе региона.

При расчете цен для проведения государственных закупочных и товарных интервенций учитываются сложившийся уровень рыночных цен реализации на сельскохозяйственную продукцию, сырье и продовольствие по регионам РФ и цен на импортируемую, завозимую продукцию. Прежде всего, сильна зависимость от времени и сроков завоза товаров из-за пределов республики. В настоящее время растет завоз продовольствия из других регионов, при этом необходимо учитывать, что численность населения Якутии за прошедшие десятилетия выросла за счет несельскохозяйственного населения. Ведущее место в экономике занимают добывающие отрасли промышленности. Сельские улусы как поставщики местного продовольствия, как правило, не должны были бы снабжаться завозным продовольствием, за исключением случаев, когда нет соответствующих условий для его производства, а также транспортная схема не позволяет организовать внутри региональные перевозки. В целом громадный по территории регион обязан соблюдать принципы продовольственной безопасности. Как показывает опыт (птичий, свиной грипп, другие эпизоотии глобального масштаба, засухи, всемирное потепление климата и т. п.) надежда на глобальный продовольственный рынок всегда должна быть подкреплена способностью региона самостоятельно прокормиться. Не будет излишним необходимость обеспечения региона собственным продовольствием независимо даже от внутригосударственных резервов, если вспомнить годы войны, «централизации» и «концентрации» 60-х гг. и т. д. 
Основные продукты питания, такие как мука, сахар, молочные продукты и в том числе мясо в основном завозятся из Республики Бурятия, Алтайского края, Новосибирской, Томской, Омской областей и др., так как местная продукция проигрывает в ценовой конкуренции. Себестоимость местной продукции, учитывая суровые природно-климатические условия, удаленность сельскохозяйственных товаропроизводителей от рынков сбыта в условиях отсутствия транспортной инфраструктуры, всегда будут выше завозного продовольствия. В связи с этим, цены на местную продукцию должны регулироваться государством, с целью поддержки местного товаропроизводителя. Очевидно, что государственное регулирование не должно подменять функции рынка или затруднять действие его законов. Основной его задачей является смягчение нежелательных последствий проявлений рыночной стихии. Одной из основных способов регулятивного характера является товарная интервенция.

Авторами исследованы цены на сельскохозяйственную продукцию в торговых точках г. Якутска, где основной объем местной говядины и овощной продукции продают во время осенней сельскохозяйственной ярмарки и в период забоя скота начиная со середины октября и до начала декабря. На ярмарку съезжаются сельскохозяйственные товаропроизводители близлежащих улусов чтобы реализовать продукцию. Традиционно из-за климатических условий региона ранней осенью горожане покупают меньше мяса, но больше овощной продукции местного производства. Только с октября до начала декабря заметно больше мяса говадины и жеребятины закупается жителями города. В остальное время на рынке реализуется завозная мясная продукция. Иногда продавцы и даже производители мяса продают привозные мясопродукты под видом местной. Из общего объема завоза $90 \%$ поставляется из соседней Бурятии, где цена говядины составляет от 220 до 280 руб. за кг, а в оптовых магазинах - от 320 до 350 руб. за кг. На оптовой базе г. Якутска «Чернышевского 80» продают даже такие экзотические для нашего региона разновидности мяса как баранина из Республики Молдова - 300 руб./кг., буйволятина из Индии - 365-380 руб./кг. Из разных видов мяса только говядина, конина (жеребятина) и оленина являются местными (табл. 1).

Таблица 1

Рыночные цены на основные продукты животноводства в г. Якутске по состоянию на начало 2019 2., руб./кг

\begin{tabular}{|c|c|c|c|c|c|c|c|c|}
\hline Название региона & Говядина & Конина & Свинина & Птица & $\begin{array}{l}\text { Молоко } \\
\mathbf{3 , 5 \%}\end{array}$ & $\begin{array}{c}\text { Сливки } \\
\mathbf{3 5 \%}\end{array}$ & $\begin{array}{c}\text { Масло } \\
\text { сливочное }\end{array}$ & Сыр \\
\hline $\begin{array}{l}\text { Республика Саха } \\
\text { (Якутия) }\end{array}$ & $450-550$ & $550-700$ & $450-530$ & $160-215$ & $70-82$ & $\begin{array}{c}271-330 \\
(0,5 \text { л. }) \\
\end{array}$ & $480-585$ & $800-880$ \\
\hline \multicolumn{9}{|c|}{ Регионы Российской Федерации } \\
\hline Республика Бурятия & $320-400$ & - & - & - & - & - & - & - \\
\hline Омская область & - & - & $295-310$ & - & - & - & - & - \\
\hline $\begin{array}{l}\text { Новосибирская } \\
\text { область }\end{array}$ & $310-320$ & - & & & & - & - & 395 \\
\hline Красноярский край & - & - & - & - & 66 & - & - & - \\
\hline Алтайский край & $310-365$ & - & 370 & - & - & - & $\begin{array}{l}110-333 \\
(500 \text { г.) }\end{array}$ & $462-982$ \\
\hline Волог.ская область & - & - & - & - & 82 & - & - & - \\
\hline Московская область & - & - & - & - & 101,75 & $\begin{array}{c}207 \\
(350 \text { г. })\end{array}$ & - & 412 \\
\hline Ленинградская область & - & - & - & - & 75,90 & - & - & - \\
\hline Белгородская область & - & - & - & - & 129 & $167-339$ & - & - \\
\hline Иркутская область & - & - & - & - & 74 & - & - & - \\
\hline Воронежская область & - & - & - & 186 & - & - & - & 568 \\
\hline Тамбовская область & - & - & - & $160-295$ & - & - & - & 592 \\
\hline
\end{tabular}




\begin{tabular}{|c|c|c|c|c|c|c|c|c|}
\hline Кабардино-Балкария & - & - & - & - & - & - & - & 438 \\
\hline Ставропольский край & - & - & - & - & - & - & - & 513 \\
\hline Республика Мордовия & - & - & - & - & - & - & - & 615 \\
\hline \multicolumn{9}{|c|}{ Страны СНГ } \\
\hline Армения & - & - & - & - & - & - & - & $848-880$ \\
\hline Белоруссия & - & - & - & $165-203$ & - & - & 470 & $544-1223$ \\
\hline \multicolumn{9}{|c|}{ Зарубежные страны } \\
\hline Аргентина & $350-355$ & - & - & - & - & - & - & $536-913$ \\
\hline Бразилия & - & - & - & 170 & - & - & - & - \\
\hline Иран & - & - & - & - & - & - & - & 1141 \\
\hline Щвейцария & - & - & - & - & - & - & - & 848 \\
\hline Сербия & - & - & - & - & - & - & - & $\begin{array}{c}135-150 \\
(250 \text { г.) }\end{array}$ \\
\hline
\end{tabular}

Источник: составлено авторами

Из табл. 1 видно, что в среднем стоимость привозного мяса -320 руб./кг, а местного - 420-450 руб./кг, привозное сливочное масло - 450 руб./кг, местное - 550 руб./кг. Цены на остальную привозную продукцию растениеводства также ниже, чем на местную в среднем на 30-70\%.

Главная причина такой ситуации заключается в высокой себестоимости производства местной продукции. Вполне очевидно, что без помощи государственного субсидирования невозможно решить эту проблему. Так как покупательская способность населения невысокая они предпочитают приобретение дешевой продукции, а местная продукция залеживается на прилавках еще 3-4 месяца.

Основными поставщиками местного картофеля и овощей (капуста, морковь и свекла) являются пригороды г. Якутска, улусы, расположенные на крупных долинах реки Лена. Некоторая часть местной продукции поставляется в северные улусы региона (табл. 2).

Таблица 2

Рыночные цены на основные продукты растениеводства в 2. Якутске по состоянию на начало 2019 2., руб./кг

\begin{tabular}{|c|c|c|c|c|c|c|c|c|}
\hline \multirow[b]{2}{*}{ Название регионов } & \multicolumn{6}{|c|}{ Овощи } & \multicolumn{2}{|c|}{ Дикоросы } \\
\hline & Картофель & Морковь & Свекла & Kanycma & Помидоры & $\underset{\substack{\text { bl } \\
\text { Ozyp }}}{ }$ & $\begin{array}{l}\text { Брусника } \\
\text { (морожс.) }\end{array}$ & $\begin{array}{l}\text { Голубика } \\
\text { (морожс.) }\end{array}$ \\
\hline $\begin{array}{l}\text { Республика Саха } \\
\text { (Якутия) }\end{array}$ & $60-100$ & $65-200$ & $50-200$ & $30-65$ & - & 330 & $250-350$ & $450-500$ \\
\hline \multicolumn{9}{|c|}{ Регионы Российской Федерации } \\
\hline Омская область & 60 & - & $50-65$ & - & - & - & - & - \\
\hline Новосибирская область & - & - & - & - & - & $\begin{array}{l}300- \\
375\end{array}$ & - & - \\
\hline Алтайский край & - & - & - & - & - & - & - & - \\
\hline Волог.ская область & - & - & - & - & - & - & - & - \\
\hline Московская область & - & - & - & - & - & - & - & - \\
\hline Иркутская область & 38 & - & - & - & - & - & - & - \\
\hline Амурская область & 50 & 70 & 50 & - & $175-200$ & $\begin{array}{l}200- \\
250\end{array}$ & - & - \\
\hline Приморский край & - & 85 & - & - & 250 & 180 & - & - \\
\hline Краснодарский край & - & - & - & - & - & - & - & - \\
\hline \multicolumn{9}{|c|}{ Зарубежные страны } \\
\hline KHP & 50 & $50-85$ & 60 & 40 & $140-170$ & $\begin{array}{c}150- \\
170\end{array}$ & - & - \\
\hline
\end{tabular}

Источник: составлено авторами

С декабря на рынке г. Якутска резко уменьшается объем продажи местных овощей и картофеля. С этого времени начинают преобладать на рынке овощи из КНР, Омской, Новосибирской, Вологодской, Московской Иркутской и Амурской областей, Приморского, Краснодарского, Алтайского краёв. Примерно $80 \%$ фруктов в регион привозят из Китая. $70-80 \%$ плодов цитрусовых культур и орехов привозят из стран Ближнего и Среднего Востока (Турция, Иран, Афганистан, Египет), а также из стран СНГ (Узбекистан, 
Таджикистан, Молдова, Армения, Киргизия). Из других зарубежных стран (Бразилия, Аргентина, Новая Зеландия, ЮАР, Марокко, ОАЭ) привозят фрукты очень редко. При этом из общего объема завоза из стран Ближнего и Среднего Востока преобладающую часть занимают цитрусовые культуры, сухофрукты и орехи. Из дикоросов только брусника и голубика являются местными, остальные ягоды в основном привозят из Китая и продают на рынке г. Якутска под видом ягод из других регионов РФ.

Товарные интервенции в республике были осуществлены еще в 2004 г. в отношении мяса, сливочного масла и овощной консервации. Тогда за год поступило сельскохозяйственной продукции на сумму 42,3 млн руб., из них реализовано на сумму 27,4 млн руб. Недопоставка продукции составляла 22,7 млн руб., в том числе: масло животное - 21,5 млн руб., говядины - 20,2 млн руб., овощной консервации - 277.54 млн руб. За последние годы в республике не применяют механизм ценового регулирования путем использования товарной интервенции. Ниже приводится предполагаемый положительный результат от применения товарной интервенции в сельскохозяйственном производственном кооперативе (далее - СХПК) «Чурапча» Чурапчинского улуса (табл. 3).

Таблица 3

Примерные расчеты по объемам закупок и реализации продукции

\begin{tabular}{|c|c|c|c|c|c|c|c|c|}
\hline \multirow[b]{2}{*}{ Показатели } & \multicolumn{4}{|c|}{ Мясо (говядина) } & \multicolumn{4}{|c|}{ Молоко } \\
\hline & $\begin{array}{c}\text { Объем, } \\
\text { тони }\end{array}$ & $\begin{array}{c}\text { Закуn. } \\
\text { цена, } \\
\text { тыс. } \\
\text { руб. }\end{array}$ & $\begin{array}{c}\text { Цена } \\
\text { реализац } \\
\text { ии, тьсс. } \\
\text { руб. }\end{array}$ & $\begin{array}{c}\text { Интер- } \\
\text { венция, } \\
\text { тыс. } \\
\text { руб. }\end{array}$ & $\begin{array}{c}\text { Объем, } \\
\text { тони }\end{array}$ & $\begin{array}{c}\text { Закуn. } \\
\text { цена, } \\
\text { тыс. } \\
\text { руб. }\end{array}$ & $\begin{array}{c}\text { Цена реализ- } \\
\text { ации, тысс. } \\
\text { руб. }\end{array}$ & $\begin{array}{l}\text { Интервенция, } \\
\text { тыс. руб. }\end{array}$ \\
\hline План закупа на 2018 г. & 300 & 120000 & & & 8500 & 425000 & & \\
\hline Фактически поступило & 238 & 95200 & & & 7800 & 390000 & & \\
\hline $\begin{array}{l}\text { Фактически } \\
\text { реализовано }\end{array}$ & 127 & & 57150 & & 3120 & & 249600 & \\
\hline $\begin{array}{l}\text { Расчет закупа на } 2019 \\
\text { г. }\end{array}$ & 320 & 128000 & 144000 & 16000 & 8200 & 410000 & 656000 & 246000 \\
\hline
\end{tabular}

Источник: составлено авторами

На основании наших расчетов предлагается следующая схема проведения товарной интервенции в республике (табл. 4).

Таблица 4

Расчет товарной интервенции в Республике Саха (Якутия)

\begin{tabular}{|c|c|c|c|c|c|c|c|c|c|}
\hline \multirow[t]{2}{*}{$\begin{array}{c}\text { Наименование } \\
\text { продукции }\end{array}$} & \multirow[t]{2}{*}{$\begin{array}{l}\text { Объем, } \\
\text { т. }\end{array}$} & \multicolumn{2}{|c|}{ Закупочная цена } & \multicolumn{2}{|c|}{ Розничная цена } & \multicolumn{2}{|c|}{$\begin{array}{c}\text { В том числе, } \\
\text { накладные расходы } \\
(14,5 \%) \\
\end{array}$} & \multicolumn{2}{|c|}{$\begin{array}{c}\text { Товарная } \\
\text { интервенция }\end{array}$} \\
\hline & & руб./к2 & mыс. руб. & pуб./кz & mыс. pуб. & $p y \sigma . / \kappa 2$ & mulc. pyб. & руб./к2. & mbic. pyб \\
\hline Говядина & 500 & 450 & 225000 & 350 & 175000 & 50 & 25000 & 100 & 50000 \\
\hline Оленина & 300 & 300 & 90000 & 200 & 60000 & 30 & 9000 & 100 & 30000 \\
\hline Свинина & 100 & 400 & 40000 & 300 & 30000 & 40 & 4000 & 100 & 10000 \\
\hline Рыба & 500 & 300 & 150000 & 250 & 125000 & 35 & 17500 & 50 & 25000 \\
\hline $\begin{array}{l}\text { Масло } \\
\text { сливочное }\end{array}$ & 500 & 480 & 240000 & 400 & 200000 & 60 & 30000 & 80 & 40000 \\
\hline Итого: & & & 745000 & & 590000 & & 85500 & & 155000 \\
\hline
\end{tabular}

Источник: составлено авторами

В настоящее время в республике производство мяса составляет около 30 тыс. тонн. Если товарной интервенцией будет охвачено 10 тыс. тонн, то это составит 100 млн руб. расходов в бюджете Республики Саха (Якутия), а при 20 
тыс. тонн - 200 млн руб.

Республика Саха (Якутия) занимает первое место в России по запасам речных деликатесных видов рыб. Вследствие некоторых неблагоприятных факторов, экспортный потенциал республики по поставкам рыбной продукции за пределы республики и РФ не в полной мере реализуется. Такими факторами являются, например, низкий уровень технической оснащенности и материально-технической базы рыбодобывающих предприятий и предприятий переработки рыбы, что приводит к излишним издержкам и порче продукции. Отсутствуют современные базы хранения и переработки рыбы, средства транспортировки продукции, нехватка специалистов, качество переработки ценных сортов рыбы не соответствует мировым стандартам. Имеется возможность поставки рыбы не только в другие российские регионы, но и в Китай. Китайские партнеры заинтересованы в экспорте как речной (муксун, налим, щука, омуль), так и озерной (карась) рыбы. Но чтобы начать экспорт в КНР, необходимо наладить систему заготовок, создать товарное производство и экспортировать полностью соответствующую международным стандартам готовую продукцию, а не сырье. В данном вопросе без помощи государства, как пишут эксперты, невозможно добиться коренного перелома [4].

В 2015 г. финансирование отрасли рыболовства в Якутии была увеличена по сравнению с 2014 г. на 65 млн руб. - до 177 млн руб. за счет средств бюджета республики. Планировалось строительство нового рыбоводного завода на среднем течении Лены для воспроизводства рыбы, для чего уже тогда начались исследования по оценке запасов биоресурсов в основных промысловых водоемах Якутии. Сейчас Якутия поставляет рыбную продукцию на Дальний Восток (в Еврейскую автономную область, Амурскую и Магаданскую области, Хабаровский край). В этих регионах предприятиями Якутии были открыты более 30 торговых площадок [17]. В экспорте рыбной продукции в КНР способствует: во-первых, географическая близость, огромный рынок сбыта; во-вторых, соответствие потребительским вкусам населения - рыба поставляется свежемороженая, без дополнительной переработки, экологически чистый продукт, что встречается в Китае крайне редко вследствие сильной загрязненности водоемов. По нашим расчетам, в перспективе, с увеличением добычи рыбы возможно увеличение объемов экспорта. По прогнозным данным, при квоте экспорта в 1000 тонн объем валютной выручки составит около 2000 тыс. долл. США.

\section{Комментарии правил закупочных интервенций Правительства РФ}

Последняя редакция Постановления Правительства Российской Федерации [1] значительно расширяет полномочия государственного федерального интервенционного фонда сельскохозяйственной продукции (рис. $1)$.

Практическая реализация интервенций всегда должна иметь ввиду, что данный инструмент обоюдо острый, как пишут эксперты [4]. История интервенций изобилует примерами сверхнормативного по срокам, по условиям хранения, значительных убытков, возмещаемых бюджетом, изначально некачественной продукции и т.д. При этом необходимо превалирование 
рыночной ориентации сельскохозяйственных товаропроизводителей при любых формах их государственной поддержки [5].

Минсельхоз Республики Саха (Якутия) имеет достаточный практический опыт государственного регулирования рынка сельскохозяйственной продукции местного производства и опытных агентов - субъектов хозяйственной деятельности, чтобы сформировать государственного агента - регионального интервенционного фонда и агентов по хранению, транспорту, переработке, страховке и реализации местной сельскохозяйственной продукции.

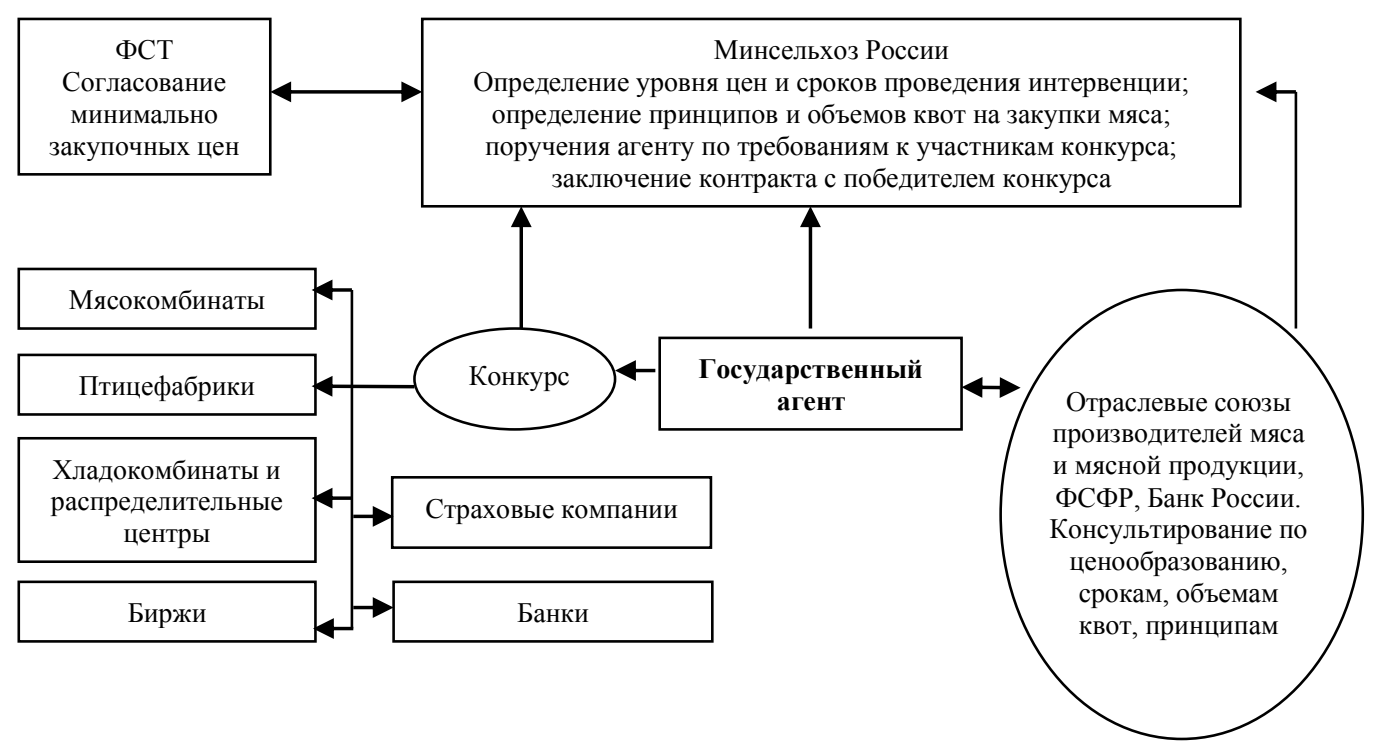

Рис. 1. Блок-схема деятельности Федерального интервенционного фонда государственного агента Минсельхоз РФ по организации закупочных и торговых интервенций с целью регулирования рынка сельскохозяйственной продукции на территории РФ

Источник: составлено авторами

\section{Выводы}

Учитывая региональные, территориальные, природно-климатические факторы функционирования агропромышленного комплекса, Государственному Собранию республики необходимо принять закон «О закупочной и товарной интервенции», который дал бы законодательную основу для разработки механизмов и правил осуществления товарных и закупочных интервенций, нацеленных на гарантированную государством закупку и реализацию продукции местных сельскохозяйственных товаропроизводителей по ценам, покрывающим их затраты с определенной рентабельностью.

Правила интервенций, утвержденные Постановлением Правительства Российской Федерации, необходимо нацелить на продовольственную безопасность региона, обеспечиваемую ростом объемов местной сельскохозяйственной продукции, гарантированно реализуемой по паритетным ценам [1]. 


\section{Список источников / References}

1. Постановление Правительства РФ от 5 октября 2016 г. № 1003 (в ред. от 25.09.2018 № 1136) «Об утверждении Правил приобретения сельскохозяйственной продукции у сельскохозяйственных товаропроизводителей и (или) организаций и индивидуальных предпринимателей, осуществляющих первичную и (или) последующую (промышленную) переработку сельскохозяйственной продукции, произведенной сельскохозяйственными товаропроизводителями на территории Российской Федерации, в процессе проведения государственных закупочных интервенций и её реализации».// http://www.consultant.ru/. Дата обращения 15.12.2018 г.

2. Официальный сайт АО «Объединенная зерновая компания» http://aoozk.com/ Дата обращения 18.12.2018 г.

3. https://www.agroinvestor.ru/ Дата обращения 22.12.2018 г.

4. Аварский Н.Д., Пролыгина Н.А., Гасанова Х.Н., Федюшкин Д.Ю. Государственные интервенции как форма маркетингового регулирования рынка зерна. Экономика сельского хозяйства России, 2014, № 6, cc.12-18. [Avarskiy N.D., Prolygina N.A., Gasanova KH.N., Fedyushkin D.Y. Gosudarstvennyye interventsii kak forma marketingovogo regulirovaniya rynka zerna [Government intervention as a form of marketing regulation of the grain market]. Ekonomika sel'skogo khozyaystva Rossii= Economics of Agriculture of Russia, 2014, no 6, pp.12-18.]

5. Micheels, E.T., Boecker, A.B. Competitive strategies among Ontario farms marketing direct to consumers. Agricultural and Food Economics, 2017, vol. 5, Issue1, no 10. https://www.scopus.com/sourceid/21100817122?origin=recordpage. Дата обращения 13.01.2019 г.

6. Looney, Kristen. 2012. The Rural Developmental State: Modernization Campaigns and Peasant Politics in China, Taiwan and South Korea. Doctoral dissertation, Harvard University. http://nrs.harvard.edu/urn3:HUL.InstRepos:9807308

7. Daoud Adel, Bernhard Reinsberg, Alexander E. Kentikelenis, Thomas H. Stubbs, Lawrence P. King. 2018. Qualitative and Quantitative data for "The International Monetary Fund's Interventions in Food and Agriculture: An Analysis of Loans and Conditions." DOI: 10.1016/j.foodpol.2019.01.005.

8. Косякин А.С. Зерновые интервенции - «старый-новый» механизм. ЭТАП: экономическая теория, анализ, практика, 2009, № 1, cc.74-77. [Kosyakin A.S. Zernovyye interventsii - «staryy-novyy» mekhanizm. [Grain interventions are the "old new" mechanism]. ETAP: ekonomicheskaya teoriya, analiz, praktika= STAGE: economic theory, analysis, practice, 2009, № 1, pp. 74-77.]

9. Фищенко В.А. Закупочные интервенции при регулировании зерновой отрасли: интервенция как метод государственного регулирования в зерновом подкомплексе АПК. Российское предпринимательство, 2011, № 2, сc. 114-117. [Fishchenko V.A. Zakupochnyye interventsii pri regulirovanii zernovoy otrasli: interventsiya kak metod gosudarstvennogo regulirovaniya $\mathrm{v}$ zernovom podkomplekse APK. [Procurement interventions in the regulation of the grain industry: intervention as a method of state regulation in the grain sub-complex of the agro-industrial complex] Rossiyskoye predprinimatel'stvo= Russian Entrepreneurship, 2011, No. 2, p. 114-117.]

10. Renata Marks-Bielska. Factors shaping interventional policy in agricultural sector / Renata Marks-Bielska. ENGINEERING FOR RURAL DEVELOPMENT Jelgava, 24.26.05.2017. pp. 1421-1426

11. Закон Республики Саха (Якутия) от 4 окт. 2002 г. 47-3 № 429-II. «О Перечне труднодоступных и отдаленных местностей в Республике Саха (Якутия)».// http://www.consultant.ru/. Дата обращения 02.04.2019 г.

12. Статистический ежегодник Республика Саха (Якутия): Стат. сборник. / Территориальный орган Федеральной службы государственной статистики по Республике Саха (Якутия). - Якутск, 2018. - 709 с. 
13. Джастин Йифу Лин Демистификация китайской экономики Cambridge Unversity Press. 2012. М.: «Мысль», 2013. 384 с. [Dzhastin Yifu Lin Demistifikatsiya kitayskoy ekonomiki Cambridge Unversity Press. 2012 [Demystification of the Chinese economy Cambridge Unversity Press] M.: M .: Thought, 2013. 384 p.]

14. Макконнелл Кэмпбелл Р., Брю Стэнли Л. Экономикс: принципы, проблемы и политика. Учебник. 14 издание. Кэмпбелл Р. Макконнелл, Irwin McGraw-Hill. 14 издание. Перевод с англ. М.; «ИНФРА-М». 2002. 972 с. [Makkonnell Kempbell R., Bryu Stenli L. Ekonomiks: printsipy, problemy i politika [Economics: Principles, Problems and Policies]. M.; «INFRA-M». 2002. 972 p.]

15. Стиглиц, Джозеф Юджин. Экономика государственного сектора. / Пер, с англ. М.: Изд-во МГУ: ИНФРА-М, 1997. - 720 c.[Stiglits, Dzhozef Yudzhin. Ekonomika gosudarstvennogo sektora [Economy of the public sector.].Per, from English. - M .: Moscow State University Publishing House: INFRA-M, 1997. - 720 p.]

\section{Сведения об авторе /About author}

Пахомов Александр Алексеевич, доктор экономических наук, главный научный сотрудник отдела региональных экономических и социальных исследований, ЯНЦ СО РАН. 677000 Россия, г. Якутск, ул. Петровского, 2. ORCID ID: 0000-0003-2942-5718.

Alexander A. Pakhomov, Doctor of Economic Sciences, Chief Researcher, Department of Regional Economic and Social Research, NSC SB RAS. 2, Petrovskogo str., Yakutsk, Russia 677000.

ORCID ID: 0000-0003-2942-5818.

Дарбасов Василий Романович, доктор экономических наук, профессор, ведущий научный сотрудник отдела региональных экономических и социальных исследований, ЯНЦ СО РАН. 677000 Россия, г. Якутск, ул. Петровского, 2. ORCID ID: 0000-0002-6755-5532

Vasiliy R. Darbasov, Doctor of Economic Sciences, Professor, Leading Researcher, Department of Regional Economic and Social Research, NSC SB RAS. 2, Petrovskogo str., Yakutsk, Russia 677000. ORCID ID: 0000-0002-6755-5532.

Охлопков Михаил Николаевич, кандидат географических наук, старший научный сотрудник отдела региональных экономических и социальных исследований, ЯНЦ СО РАН. 677000 Россия, г. Якутск, ул. Петровского, 2. ORCID ID: 0000-0001-9934-0715.

Michail N. Okhlopkov, Candidate of Geografic Sciences, Senior Researcher, Department of Regional Economic and Social Research, NSC SB RAS. 2, Petrovskogo str., Yakutsk, Russia 677000.

ORCID ID: 0000-0001-9934-0715.

Федорова Екатерина Ярославовна, кандидат экономических наук, ведущий научный сотрудник отдела региональных экономических и социальных исследований, ЯНЦ СО РАН. 677000 Россия, г. Якутск, ул. Петровского, 2. ORCID ID: 0000-0002-1980-5592.

Ekaterina Ya. Fedorova, Candidate of Economic Sciences, Leading Researcher, Department of Regional Economic and Social Research, NSC SB RAS. 2, Petrovskogo str., Yakutsk, Russia 677000.

ORCID ID: 0000-0002-1980-5592.

Соломонов Михаил Прокопьевич, кандидат экономических наук, научный сотрудник отдела региональных экономических и социальных исследований, ЯНЦ СО РАН. 677000 Россия, г. Якутск, ул. Петровского, 2. ORCID ID: 0000-0003-1838-6303.

Mikhail P. Solomonov, Candidate of Economic Sciences, Researcher, Department of Regional Economic and Social Research, NSC SB RAS. 2, Petrovskogo str., Yakutsk, Russia 677000.

ORCID ID: 0000-0003-1838-6303. 